\title{
Science and Public Policy, Historically Speaking
}

\author{
James A. Guikema
}

Associate Vice Provost for Research, Associate Dean of the Graduate School

Kansas State University

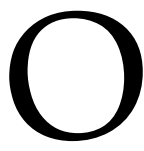

nce again the theme of this Merrill Conference is timely; multiple public policy

issues are having an impact on the enterprise of scientific research. Some of these issues impose systemic limitations on the 'how' of our research activities.

For example, several years ago at this conference, we discussed constraints imposed by the Student and Exchange Visitor Information System (SEVIS) regulations and the impact on research and training of foreign national graduate students. These restrictions continue, and international student applications to U.S. graduate schools are at an all-time low. Others of these issues seek to limit the 'what' of our research efforts. An example raised by many speakers at this conference has been the use of human embryonic stems cells in biomedical research.

This text takes a slightly different approach by examining historical examples where public policy decisions collided with the science research enterprise. I am not a historian; this is a biologist's look at history. Yet it is important to realize that national administrative decisions can profoundly focus our enterprise, even as we seek to provide our policy makers with decisionquality information. Therefore, through the perspective of history we will focus on two obvious questions - which lead to a research compliance concern.

Question 1: Can policy decisions shape the future of science?

The answer to this question is, quite obviously, yes. Government largely provides the funding for scientific research, and despite the concept of peer review Washington feels free to set research agendas. For example, why does the Navy fund a major cancer research program?

Choice of the historical example highlighted in this talk was motivated by two crown jewel resources available here in the Midwest: the Eisenhower Library and Museum in Abilene, Kansas, and the Kansas Cosmosphere and Space Center (KCSC) in Hutchinson. K-State was fortunate to host a number of undergraduate research scholars during the past summer, and the K-State Graduate School invited them on a trip to the KCSC. KCSC tells a remarkable story of the U.S. commitment to the space program. Much of this commitment grew during the Eisenhower presidency - as is reinforced by exhibits at the Eisenhower Library and Museum-and it certainly led the way to the robust science programs we see today. 
The Eisenhower presidency made a major decision that set the stage for initial losses in the space 'race,' which I believe set the stage for the larger victory. The decision had its roots in events during World War II. In February 1945, Stalin, Churchill, and Roosevelt met to divide Germany. Stalin was ecstatic, since the Russian zone would contain the major weapons and missile development region: Peenemünde.

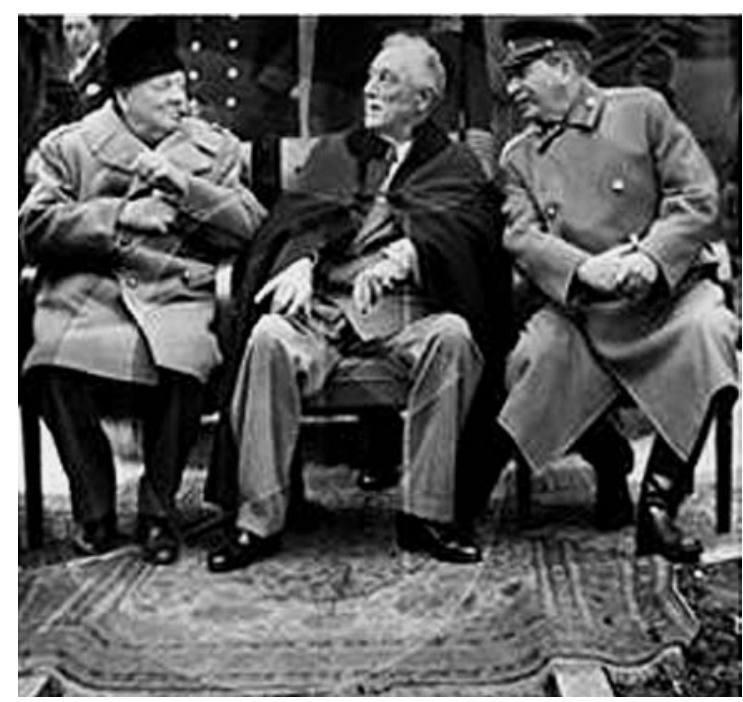

Churchill, Roosevelt and Stalin at the conference in Yalta at which the fate of Germany was decided. (NASA file photo.)

In June of 1945, however, Dr. Warner von Braun surrendered to U.S. troops, and Secretary of State Cordell Hull approved moving von Braun, 126 members of his staff, and 300 train cars of V2 rockets and missile parts to the U.S.. Stalin was furious and launched an aggressive missile development program immediately following the war.

When Eisenhower assumed the presidency, there were two groups - the Army (von Braun et al.) and the Navywho were active in missile development. Eisenhower added a third-a civilian effort that later became NASA. Further, he mandated that any progress in orbital spaceflight be made in a civilian effort.

Though in ancient times Seneca (4 B.C.-39 A.D.) wrote, "There is no easy way between the Earth and the stars," von Braun made tremendous progress from 1948 to 1954 with the Redstone rocket. Yet in 1955 he was told in no uncertain terms to stop all efforts in satellite launch. Eisenhower announced an orbital flight program in 1956, with the disaster-prone Vanguard program in the lead. On May 22, 1956, the Secretary of Defense announced that "there are no plans or preparations using Redstone or the new Jupiter missiles as launch vehicles." Von Braun's team was shut out, despite overwhelming superiority, because it was a military, not civilian, operation.

On September 20, 1956, a Jupiter C rocket achieved escape velocity, but did not have permission to orbit. In August 1957, a Jupiter C nosecone was retrieved-the first ever recovery following spaceflight (again, no orbital permission). Jules Verne said that "Anything that one man can imagine, other men can make real." The Soviets proved the saying by launching Sputnik I (October 4, 1957) and Sputnik II (November 3, 1957), and the U.S. lost the space war: part 1.

In a complete reversal, on November 7, 1957, Eisenhower announced that the Jupiter (von Braun's) program had solved all of the U.S. problems and that orbital flight was near. In January of the following year, Explorer I was launched; it put into orbit a radiation sensing payload developed by a University of Iowa colleague, Professor James van Allen. 


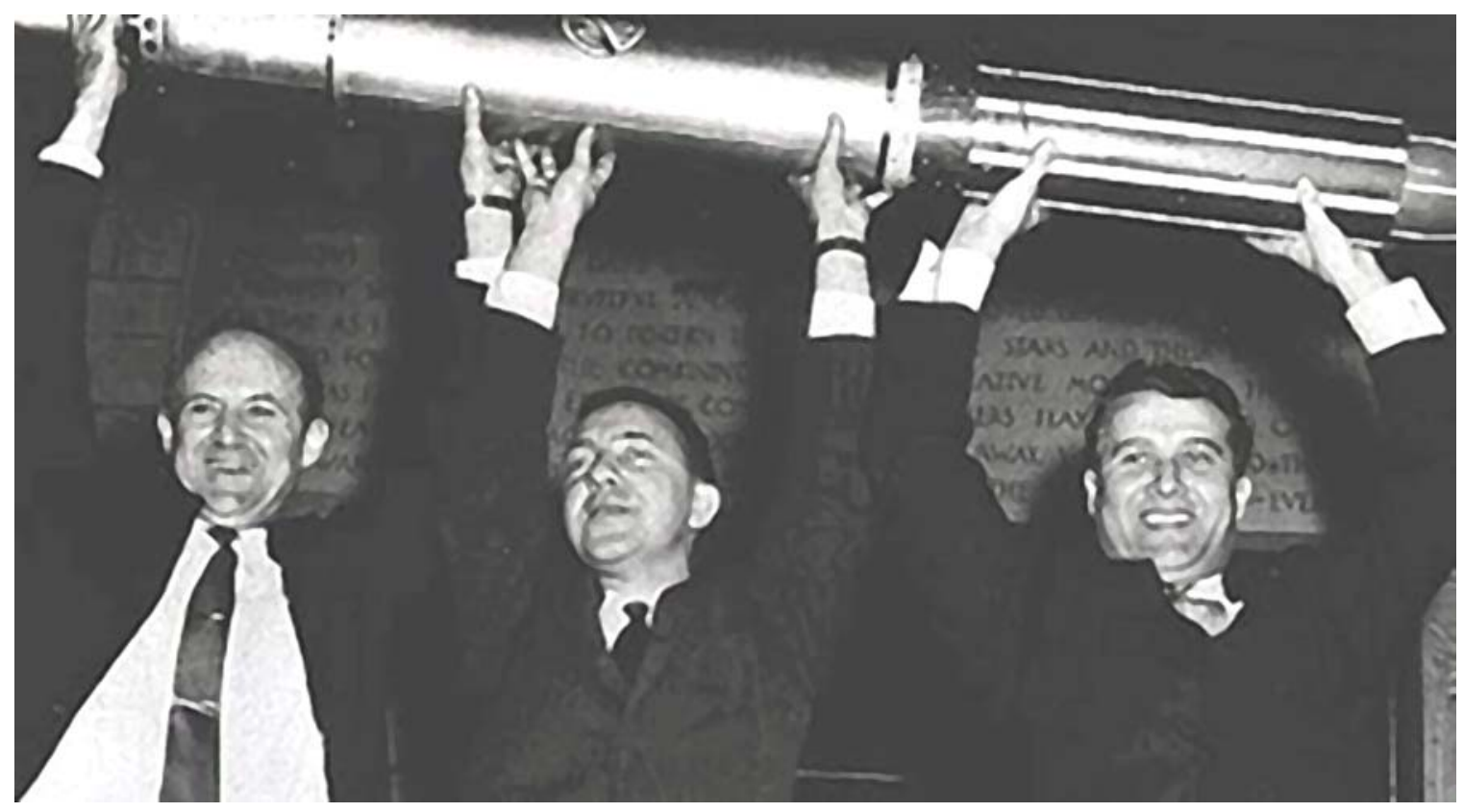

Dr. Warner von Braun (far right), Jet Propulsion Laboratory Director James Pickering, and State University of lowa Professor James van Allen showing a model of Explorer I following the first successful U.S. orbital missile launch. (NASA file photo.)

The U.S. lost phase one of the space race because of Eisenhower's pro-civilian policies. Kennedy, however, needed to reclaim international leadership. He asked his staff to recommend strategies, and Lyndon Johnson provided the answer-put a man on the moon. The Apollo program had begun.

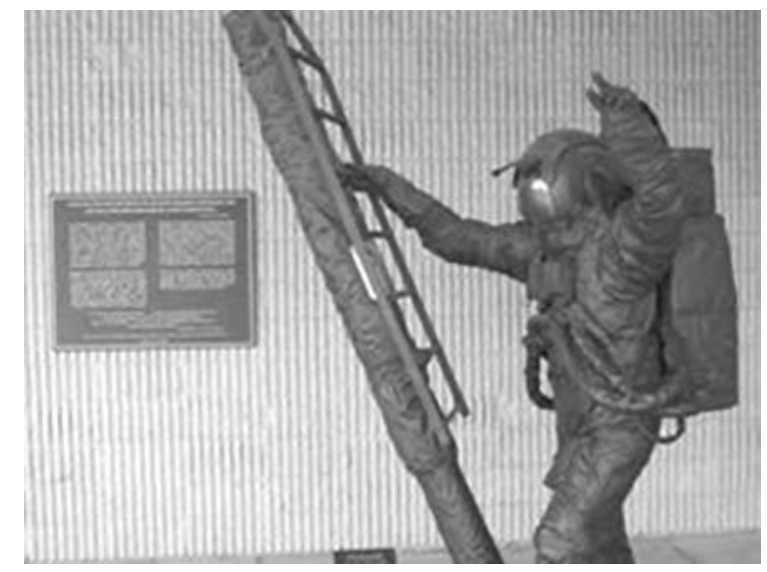

Tribute to the last footprint left on the moon in 1972 at the Kansas Cosmosphere \& Space Center. (Personal photo by the author.)
The last human footprint on the moon occurred on December 13, 1972, left by Apollo 17 commander Cernan. (Coincidently, University of Kansas graduate Ronald Evans was on the mission.) Would we have gone to the moon if Eisenhower had won the race to orbital spaceflight? I think not.

Question 2: Can (bad) science shape the future of public policy?

For a historical example of science shaping public policy, I turned to our Vice Provost for Research, Dr. R.W. Trewyn for a suggestion. His suggested example illuminates activities during the Viet Nam War, when the U.S. extensively used defoliants like Agent Orange to deny terrain to the enemy.

Dr. Trewyn was asked to be a consultant on a study of the health effects on soldiers involved in herbicide 
application. The accompanying photo shows that little personal protective equipment was used, and that adverse conditions such as prop-wash from helicopters did not deter spraying. As

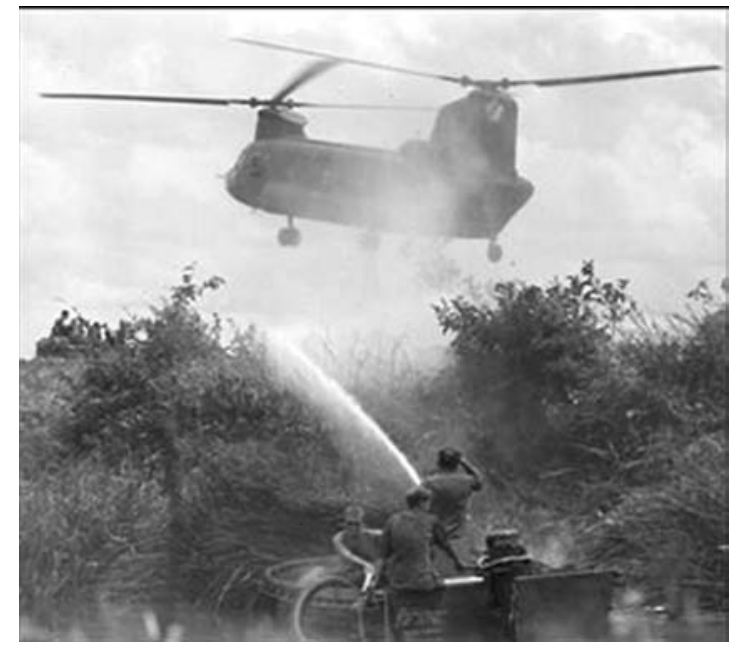

The spraying of herbicide-likely Agent Orange-in Viet Nam without the use of personal protective equipment. (U.S. Army file photo)

part of his efforts, Dr. Trewyn was asked to testify to the National Affairs, Veterans Affairs, and International Affairs Subcommittee of the House Committee on Governmental Reform. The focus was on the Air Force Ranch Hands Study on the Health Effects of Agent Orange (March 2000). And his message was this: the study was flawed, because the control group was inappropriate.

The U.S. government had based its treatment of veteran soldiers on a flawed study. Even though the flaws were unearthed, the science team refused to change the parameters during the two decades of the study. Bad science helped to create bad policy.
Are there implications for the research administrator?

As mentioned earlier, my last presentation to this audience concerned SEVIS and its impact on our international graduate student clients. My example addressing this question involves foreign-born students as well, but the impact is on our faculty scientist, not on the student.

Export control regulations are not new. Rather, they are decades old and they have their roots in political differences amongst nations. Export from the U.S. is liberal to Canada and Mexico, but almost nothing can be exported to Cuba or North Korea. The political climate for the university researcher changed dramatically, however, in 1994, when information - the results of university scientific research - became an export commodity.

Export Administration Regulations (EAR) are administered by the U.S. Department of Commerce and regulate items that could be mutually used for business or for defense (such as global positioning systems). International Traffic in Arms Regulations (ITAR) are administered by the U.S. Department of State to regulate weapons and related items. EAR violations can result in faculty members being fined up to $\$ 1$ million and 10 years imprisonment, while ITAR violations can result in $\$ 100,000$ fines and two years imprisonment. The faculty member, not the university, is personally liable.

Since 1994, the concept of 'deemed export' has come into play. Simply put, in order to convey restricted information or protected software code to a foreign coworker (undergraduate student, 
graduate student, postdoctoral, or faculty colleague), one must first obtain an export license. The restrictions come into play when faculty members accept research contracts/agreements which (a) contain limitations on publishing the findings of research, (b) are based on the sponsor providing sensitive or confidential information which will not be published, or (c) are classified by the government.

EAR, ITAR, and the concepts of deemed exports mean that universities must add a layer onto their research compliance activities. At Kansas State University, we have begun that process. 